\title{
Peran Wanita Tani Pembuat Atap Rumbia dalam Meningkatkan Pendapatan Keluarga dalam Perspektif Ekonomi Islam (Studi Kasus di Kabupaten Konawe)
}

\author{
Beti Mulu ${ }^{1}$ dan Leni Saleh ${ }^{2}$ \\ ${ }^{1}$ Dosen Fakultas Ekonomi dan Bisnis Islam IAIN Kendari \\ Email:Betimulu@yahoo.com \\ ${ }^{2}$ Dosen Fakultas Pertanian Universitas Lakidende \\ Email: Cici raslin@yahoo.co.id
}

\begin{abstract}
Abstrack
This study aimaed ti analyze : (1) how much revenue the thatched roof maker of women farmers in increasing family incomes in Konawe, (2) how the role of women farmers in the thatched roof maker Konawe in the perspective of the Islam ekonomiy. Data collection techniques uses two ways : primary data through direct interviews using a questionnaire to a sample of respondents and secondary data obtained from recompilation literature and bibliography. Data collected were processed using descriptive statistical analysis and to analyze how much the revenue from the women farmers in district Konawe use quantitative methods of analysis.

This study concluded that the results of the analysis showed revenue earned income of women farmers maker thatched roof in Konawe already quite optimal amounting Rp.23.248.175 or an average of Rp.1.010.790 one person women farmers in an effort to make the thatched roof in a month the manufacturing process. The work done by women farmers maker thatched roofs in increasing family income is a good business and in line with Islamic law becouse it is done with effort and good intentions, which is to help boost the economiy of the family income, while permission form her husband. So it does not conflict with principles of Islamic economics, in fact, Islam forbids the muslims to stand by or asks as beggars, the homeless and other people while still being able to strive.
\end{abstract}

Keywords: The Role, Women Farmers, Family Income and Islamic Economics. 


\begin{abstract}
Abstrak
Penelitian ini bertujuan untuk menganalisis : (1) berapa besarnya pendapatan wanita tani pembuat atap rumbia dalam meningkatkan pendapatan di Kabupaten Konawe, (2). bagaimana peran wanita tani pembuat atap rumbia di Kabupaten Konawe dalam perspektif ekonomi Islam .Teknik pengumpulan data dilakukan dengan dua cara, yaitu data primer melalui wawancara langsung menggunakan kuesioner terhadap responden sampel dan data sekunder diperoleh dari hasil kompilasi literatur dan kepustakaan.. Data yang telah dikumpulkan, diolah dengan menggunakan analisis statistik deskriptif dan untuk menganalisis berapa besarnya nilai pendapatan dari wanita tani di Kabupaten Konawe digunakan metode kuantitaif analisis.

Hasil penelitian menyimpulkan bahwa hasil analisis pendapatan menunjukkan bahwa pendapatan yang diperoleh wanita tani pembuat atap rumbia di Kabupaten Konawe sudah cukup optimal yaitu sebesar Rp.23.248.175,- atau rata-rata sebesar Rp.1.010.790,- per wanita tani dalam usaha membuat atap rumbia dalam satu bulan proses pembuatan. Usaha yang dilakukan oleh wanita tani pembuat atap rumbia dalam meningkatkan pendapatan keluarga merupakan usaha yang baik dan sejalan dengan syari'at Islam karena dilakukan dengan usaha dan niat yang baik, yaitu untuk membantu meningkatkan perekonomian pendapatan keluarga, selagi mendapat izin dari suami. sehingga hal ini tidak bertentangan dengan prinsip ekonomi Islam. Bahkan Islam melarang kepada seluruh umat muslim untuk berpangku tangan atau meminta-minta sebagai pengemis, gelandangan dan lain-lain selagi umat tersebut masih mampu untuk berusaha.
\end{abstract}

Kata Kunci: Peran, Wanita Tani, Pendapatan Keluarga dan Ekonomi Islam.

\section{LATAR BELAKANG}

Sektor pertanian di Indonesia mempunyai peranan yang sangat penting dalam perkembangan pembangunan yaitu sebagai sumber kehidupan dan pendapatan petani dalam keluarga, apabila dikembangkan secara terus-menerus akan membawa dampak terhadap persoalan ketenaga-kerjaan terutama tenaga kerja wanita. Hal ini terlihat dari penyediaan lapangan kerja, penyediaan pangan, dan penyumbangan devisa negara melalui eksport. Wanita sebagai sumber insani mempunyai hak dan kewajiban serta kesempatan yang sama dengan pria dalam pembangunan di segala bidang. Disamping itu juga berperan mengembangkan generasi muda, terutama anak-anak dan remaja dalam pembangunan manusia seutuhnya. Wanita dalam kehidupan bermasyarakat disamping sebagai ibu rumah tangga juga sebagai tenaga kerja pencari nafkah baik untuk dirinya maupun keluarganya (Leni, $2010: 15)$. 
Salah satu upaya pemerintah untuk mensejahterakan masyarakatnya adalah dengan meningkatkan pembangunan keseluruh lapisan daerah termasuk pembangunan yang dilakukan pada sektor pertanian di pedesaan. Karena dengan meningkatkan pembangunan pada sektor pertanian diharapkan dapat menambah devisa yang berasal dari sektor pertanian.Dalam proses meningkatkan pembangunan pada sektor pertanian peran anatara laki-laki dan perempuan bisa setara. Hal yang bertujuan agar kehidupan rumah tangga pada petani dapat bertahan (survive) dan memperlancar ekonomi rumah tangga, diperlukan keterlibatan perempuan dalam kegiatan ekonomi tidak terlepas dari keberhasilan pembangunan di semua bidang yang memberikan peluang bagi semua perempuan untuk mendapatkan pendidikan dan kesempatan berkarir yang semakin terbuka. Adapun motivasi utama wanita di pedesaan untuk bekerja pada umumnya disebabkan karena tuntutan ekonomi keluarga dan bertujuan untuk menambah pendapatan keluarga (Dina dkk dalam Majid, 2012).

Wanita dengan berbagai aktivitas kerja sehari-hari baik yang dilakukan secara terencana maupun tidak pada dasarnya mempunyai nilai ekonomis, terutama bila dikaitkan dengan pendapatan dalam usaha membantu keluarga. Peranan wanita khususnya dalam keinginan mencari nafkah bertujuan untuk meningkatkan kesejahteraan keluarga, oleh karena itu perlu dukungan masyarakat yang semakin tinggi terhadap perluasan kesempatan berkarya bagi wanita khususnya di pedesaan. Guna meningkatkan penghasilan, peran sertawanita dalam rumah tangga sangat diharapkan. Tenaga kerja wanita dalam usaha penetasan memegang peranan yang penting, karena dalam usaha penetasan dapat menyumbangkan pendapatan yang cukup besar (Utami dkk, 2012).

Hampir 40\% wanita tani di pedesaan berasal dari golongan rumah tangga kurang mampu, sehingga tenaga mereka diperlukan untuk mencari nafkah bagi kelangsungan hidup keluarganya. Dalam perannya sebagai pencari nafkah itulah maka wanita tani di pedesaan sering berkerja serabutan, hal ini dapat terjadi karena seringkali disebabkan karena kurangnya modal serta sempitnya lahan yang dikuasi oleh keluarga wanita tani, sehingga untuk mencari tambahan pendapatan seringkali wanita tani bekerja 
sebagai buruh tani dan lain sebagainya Wanita tidak hanya berperan sebagai ibu rumah tangga, tetapi juga melakukan kegiatan produktif guna menambah penghasilan. Peran wanita dari rumah tangga berpenghasilan rendah cenderung menggunakan lebih banyak waktu untuk kegiatan produktif dibandingkan dengan pekerjaan wanita dari rumah tangga berpenghasilan tinggi (Heru, 2001).

Rumah tangga petani sebagai sumber tenaga kerja, akan bekerja untuk memperoleh upah dalam kegiatan usahatani milik keluarga. Namun dengan adanya peluang untuk bekerja di luar kegiatan usahatani mendorong petani membuat keputusan untuk mengalokasikan tenaga kerja yang tersedia menjadi lebih efisien, sehingga dapat diasumsikan bahwa dengan tingkat pendapatan usahatani yang rendah, rumah tangga petani akan memaksimalkan pendapatannya dengan jalan mengkombinasikan kegiatannya (Saad, 2006).

Menurut Winardi (2005), fenomena pencaharian pendapatan tambahan rumah tangga sudah sangat lazim terjadi. Hal ini menandai adanya keragaman dalam sumber pendapatan rumah tangga. Pendapatan rumah tangga petani berasal dari sumber yang selalu berubah sesuai dengan musim, pasar tenaga kerja, dan waktu luang setiap harinya yang dimiliki anggota keluarga petani. Pembagian pekerjaan relatif lentur diantara anggota keluarga. Hal ini menyebabkan munculnya pengambilan keputusan untuk mencurahkan waktu kerja lebih banyak ke dalam kegiatan usahatani atau aktivitas kerja selain usahatani. Perilaku pencurahan waktu kerja petani sangat dipengaruhi oleh karakteristik rumah tangga petani yang tergambar dari umur dan pendidikan suami, istri, jumlah anggota dan tenaga kerja keluarga, jumlah anak sekolah dan balita, lama menetap serta pengalaman usahatani.

Wanita memegang peran penting sebagai ibu rumah tangga dengan berbagai jenis pekerjaan dari yang berat sampai yang ringan, seperti mengatur rumah tangga, memasak, mencuci, mengasuh dan mendidik anak. Namun sejalan dengan perkembangan teknologi disektor pertanian, maka perempuan tani perlu meningkatkan pengetahuan, keterampilan sehingga dapat mengambil manfaat yang sebesar-besarnya dari segala jenis sumber daya yang ada disekitarnya berupa sumber 
daya alam maupun sumber daya manusia. Karena itu, kemajuan yang dicapai perempuan zaman sekarang dapat dijumpai pada banyak kaum hawa ini sebagai motor penggerak pembangunan dibidang pertanian, seperti kelompok tani, dalam kegiatan program peningkatan produksi pertanian, dalam kegiatan pasca panen produksi pertanian. Termasuk mengandung beban kerja dirumah tangga seperti mengambil air, mencari kayu bakar, memasak, menjual hasil panen, mendidik anak-anaknya, sebagai ibu rumah tangga dan mengabdi kepada suaminya (Nurmayasari, 2014).

Peran wanita dalam pertanian termasuk dalam ketahanan pangan dan gizi keluarga. Ketahanan pangan dapat mengembangkan kelembagaan dan pengelolaan usaha pangan bagi wanita tani, sehingga wanita harus pandai mengatur, mengelola penghasilan yang relatif rendah agar mencukupi kebutuhan keluarga terutama sandang pangan agar mampu memenuhi kebutuhan hidup spirituil dan materiil yang layak, bertaqwa kepada Tuhan Yang Maha Esa, memiliki hubungan yang serasi, selaras dan seimbang antar anggota dan antara keluarga dengan masyarakat dan lingkungan. Secara operasional keluarga sejahtera adalah keluarga yang dapat melaksanakan fungsifungsi keluarga, sehingga dalam rangka mewujudkan keluarga sejahtera perlu upaya untuk menghidupkan dan menumbuhkembangkan fungsi-fungsi keluarga tersebut. Keluarga Sejahtera yaitu keluarga yang dibentuk berdasarkan perkawinan yang sah, mampu memenuhi kebutuhan hidup spiritual, dan materi yang layak, betaqwa kepada Tuhan Yang Maha Esa, memiliki hubungan yang selaras, serasi, dan seimbang antar anggota dan antar keluarga dengan masyarakat dan lingkungan (BKKBN, 1995).

Peranan (role) merupakan proses dinamis kedudukan (status). Apabila seseorang melaksanakan hak dan kewajibannya sesuai dengan kedudukannya maka seseorang itu telah menjalankan suatu peranan. Perbedaan antara kedudukan dan peranan adalah untuk kepentingan ilmu pengetahuan dimana keduanya tidak dapat dipisahpisahkan karena yang satu tergantung pada yang lain begitu juga sebaliknya (Soekanto, 2009).

Selanjutnya Levinson dalam Soekanto (2009) mengatakan peranan mencakup tiga hal antara lain: (1) peranan meliputi norma- 
norma yang dihubungkan dengan posisi atau tempat seseorang dalam masyarakat. Peranan dalam arti ini merupakan rangkaian peraturan-peraturan yang membimbing seseorang dalam kehidupan bermasyarakat; (2) peranan merupakan suatu konsep tentang apa yang dilakukan oleh individu dalam masyarakat sebagai organisasi; (3) peranan juga dapat dikatakan sebagai perilaku individu yang penting bagi struktur sosial masyarakat. Peranan wanita yang mengkaji status atau posisi beserta perbedaan dari masingmasing anggota rumah tangga baik itu dari segi pendapatan ekonomi merupakan pengukuran imbalan curahan tenaga kerja anggota rumah tangga yang diperlukan untuk eksistensi rumah tangga dalam memenuhi konsumsi (kebutuhan) rumah tangga.

Islam telah mengajarkan bahwa motivasi dan alasan bekerja adalah dalam rangka mencari karunia Allah SWT. Tujuan bekerja adalah untuk mendapatkan harta agar seseorang dapat memenuhi kebutuhanya, menikmati kesejahteraan hidup dan perhiasan dunia. Pekerjaan yang dilakukan tersebut haruslah pekerjaan yang halal agar aktifitas bekerja ini juga bernilai ibadah. Tentunya dalam pandangan Islam agar harta yang didapatkan dari bekerja tersebut menjadi kepemilikan yang sah. Bekerja bukan merupakan sebab mendapatkan harta melainkan perwujudan dari pelaksanaan perintah syara' (Sholahuddin, 2007).

Sebagaimana Firman Allah SWT dalam surat Al-Jumu'ah ayat 10 :

Artinya: Apabila telah ditunaikan shalat, Maka bertebaranlah kamu dimuka bumi dan carilah anugrah dari Allah dan ingatlah Allah banyakbanyak supaya kamu beruntung. (2S AlJumu'ah: 10).

Bekerja merupakan bagian ibadah, yaitu perkerjaan yang dilakukan sesuai dengan rambu-rambu yang diperintahkan Allah SWT dan meninggalkan yang dilarang-Nya. Bagi mukmin yang senantiasa mentaati ajaran islam, senantiasa dalam bekerja merasa diawasi oleh Allah sehingga ia akan selalu waspada bekerja dalam rel garis Allah dan menghindari diri dari penyimpangan keridhaan Allah, menghindari diri dari malpraktik, korupsi dan lainnya dalam pekerjaan. Sehingga pekerjaanya itu bernilai ibadah yang di ridhai Allah (Zulmaisarna, 2009).

Dalam rangka meningkatkan pendapatan keluarga, wanita atau istri memiliki peran yang sangat strategis mengingat berbagai potensi yang 
dimilikinya. Peran wanita sebagai patner laki-laki dalam kehidupan keluarga akan mampu menjadi pintu masuk menuju perbaikan kesejahteraan keluarga. Berkaitan dengan perbaikan kesejahteraan keluarga maka telah menuntut perempuan untuk dapat membantu dalam menopang ketahanan ekonomi keluarga. Kondisi demikian merupakan dorongan yang kuat bagi perempuan untuk berkerja dalam menambah penghasilan.

Islam telah menjamin hak perempuan untuk bekerja sesuai dengan tabiatnya dan aturan-aturan syariat dengan tujuan untuk menjaga kepribadian dan kehormatan perempuan. Meskipun demikian, Istri harus memiliki keyakinan bahwa yang utama dalam hidupnya adalah mengatur urusan rumah tangga. Dalam konteks pekerja, perempuan dipersilahkan memilih bidang atau sektor yang disukai yang sesuai dengan kemampuan dan profesionalitas yang dimiliki. Sebagaimana Firman Allah STW berikut ini :

Artinya : Katakanlah: "Tiap-tiap orang berbuat menurut keadaannya masingmasing". Maka Tuhanmu lebih mengetahui siapa yang lebih benar jalannya.(QS. Al Isra': 84)

(Departemen Agama RI, 2002 : 290).
Upaya melibatkan wanita dalam kegiatan usaha membuat atap rumbia merupakan salah satu upaya peningkatan keamanan ekonomi keluarga dan efisiensi pemanfaatan sumberdaya lokal serta meningkatkan status gender dalam kegiatan sektoral. Keikutsertaan wanita dalam kegiatan usaha membuat atap rumbia mampu memberikan sumbangan finansial dalam bentuk peningkatan pendapatan keluarga.

Desa Tanggobu Kecamatan Lambuya merupakan salah satu sentra tempat tumbuhnya pohon rumbia karena daerahnya yang banyak rawa atau sungaisungai kecil, sehingga banyak para penduduk menggunakan fasilitas yang ada dimana sebagian penduduknya terutama wanita taninya melakukan usaha pembuatan atap rumbia disamping usaha tani lainnya. Eksistensi wanita tani sebagai pembuat atap rumbia tampaknya tidak ada unsur paksaan atau dikendalikan oleh suami atau majikannya, artinya perempuan tidak tergantung pada pihak lain yang menjadikan ia terpaksa melakoni aktifitas sebagai pembuat atap rumbia atau memaksanya untuk tinggal dan berdiam diri dirumah, mengurus rumah tangga, 
suami dan anak. Mereka memutuskan sendiri jalan yang harus dilakoninya, seperti dalam melakukan aktifitas pembuatan atap rumbia, selain membawa dampak yang positif bagi kemajuan ekonomi keluarga, juga dapat mengembangkan bakat, keterampilan, pengetahuan serta pengalaman dalam kegiatan membuat atap.

Berdasarkan uraian pada latar belakang di atas, maka tujuan dalam penelitian ini dapat dirumuskan sebagai berikut :

1. Mengetahui berapa besarnya pendapatan wanita tani pembuat atap rumbia dalam meningkatkan pendapatan keluarga di Kabupaten Konawe.

2. Mengetahui bagaimana peran wanita tani pembuat atap rumbia di Kabupaten Konawe dalam perspektif ekonomi Islam .

\section{KAJIAN PUSTAKA}

A. Peran Wanita Tani dalam Usaha Membuat Atap Rumbia

Menurut Friedman (dalam Nurmayasari, 2014 : 24)), peran adalah serangkaian perilaku yang diharapkan pada seseorang sesuai dengan posisi sosial yang diberikan baik secara formal maupun secara informal. Peran didasarkan pada preskripsi (ketentuan) dan harapan peran yang menerangkan apa yang individuindividu harus lakukan dalam suatu situasi tertentu agar dapat memenuhi harapanharapan mereka sendiri atau harapan orang lain menyangkut peran-peran tersebut. Sedangkan menurut Soekanto (1992: 102) peran adalah segala sesuatu oleh seseorang atau kelompok orang dalam melakukan sesuatu kegiatan karena kedudukan yang dimilikinya. Peran adalah perilaku yang diharapkan dari seseorang yang mempunyai suatu status (Horton, B. Paul dalam Nurmayasari, 2014: 24). Berdasarkan berbagai pendapat diatas, dapat disimpulkan bahwa peran adalah keikutsertaan individu atau kelompok dalam suatu kegiatan guna mencapai tujuan individu maupun tujuan bersama.

Kanfer (dalam Nurmayasari, 2014: 24) menyebutkan lima aspek penting dari peran, yaitu sebagai berikut :

a. Peran itu bersifat impersonal, yaitu posisi peran itu sendiri akan menentukan harapannya bukan individunya;

b. Peran itu berkaitan dengan perilaku kerja (task behavior), yaitu perilaku yang 
diharapkan dalam suatu pekerjaan tertentu;

c. Peran itu sulit dikendalikan;

d. Peran itu dapat dipelajari dengan cepat dan dapat menghasilkan beberapa perubahan perilaku utama;

e. Peran dan pekerjaan (jobs) itu tidaklah sama, seseorang yang melakukan satu pekerjaan bisa saja memainkan beberapa peran.

Menurut Soekanto (1992 : 140) menyebutkan bahwa suatu peran paling sedikit mencakup tiga hal, yaitu :

a. Peranan meliputi norma-norma yang dihubungkan dengan posisi atau tempat seseorang dalam masyarakat. Peranan dalam arti ini merupakan rangkaian peraturan-peraturan yang membimbing seseorang dalam kehidupan bermasyarakat.

b. Peran adalah suatu konsep perihal apa yang dapat dilakukan individu dalam masyarakat sebagai organisasi.

c. Peran juga dapat dikatakan sebagai perikelakuan individu yang penting bagi stuktur sosial masyarakat.

Berdasarkan ketiga hal diatas, maka dalam peran perlu adanya fasilitas-fasilitas bagi seseorang atau kelompok untuk dapat menjalankan perannya.
Potensi yang dimiliki wanita untuk menopang ekonomi keluarga memang cukup besar. Namun demikian wanita tidak menonjolkan diri atau mengklaim bahwa mereka menjadi penyangga utama ekonomi keluarga. Wanita Indonesia terutama di perdesaan sebagai sumber daya manusia cukup nyata partisipasinya khususnya dalam memenuhi fungsi keluarga dan rumah tangga bersama pria. Beberapa hasil penelitian menunjukkan peran serta wanita dalam berbagai industri di beberapa daerah cukup besar dan menentukan, dengan pengelolaan usaha yang bersifat mandiri ( Lestari,dkk, 1997).

Sumbangan wanita dalam ekonomi masyarakat dan rumah tangga maupun dalam kehidupan keluarga sangat besar dimana perkembangan masyarakat desa dewasa ini memerlukan keikutsertaan wanita. Menurut Tohir dalam Rani (2016 : 6), bahwa dalam rantai pertanian seperti penanganan, pengelolaan dan pemasaran hasil selalu dilakukan oleh wanita dipedesaan sehingga tidak mengherankan bahwa dalam beberapa halwanita ikut serta menentukan jalannya usaha. Terlibatnya wanita tani dalam proses produksi pertanian sangat besar, terlebih 
pada kegiatan pengelolaan hasil produk pertanian itu sendiri.

Peranan wanita dalam aktivitas rumah tangga berarti wanita sebagai ibu rumah tangga. Dalam hal ini wanita memberikan peran yang sangat penting bagi pembentukan keluarga sejahtera sebagai unit terkecil dalam kehidupan bermasyarakat, berbangsa, dan bernegara. Kehidupan yang sehat sejahtera harus dapat dimanifestasikan dalam kehidupan sehari-hari. Menurut Kuswardinah (2007: 134) untuk menciptakan suatu keluarga yang baik perlu didukung hal sebagai berikut :

1. Kesehatan jasmani harus diperhatikan, mulai dari kesehatan suami, istri, dan kesehatan anak sejak dalam kandungan, usia balita, hingga dewasa, gizi keluarga, hidup bersih serta teratur.

2. Kesehatan rohani harus diperhatikan, mulai dari sikap perilaku orang tua sejak anak masih dalam kandungan, mengajarkan pendidikan moral, sosial, dan agama dalam keluarga, serta menjadi tauladan bagi anak-anaknya.

3. Ekonomi keluarga yang dapat menunjang kehidupan rumah tangga, yaitu adanya keseimbangan antara pengahasilan dan pengeluaran, menentukan skala prioritas, menambah pendapatan keluarga dengan kesempatan wanita sebagai ibu rumah tangga yang bekerja atau berwiraswasta.

Wanita sebagai bagian dari keluarga mempunyai tugas-tugas antara lain sebagai istri, sebagai ibu rumah tangga, sebagai pendidik bagi anak-anaknya. Menurut Hemas (dalam Pudjiwati, 1997 : 35) memaparkan bahwa tugas yang disandang oleh seorang wanita yaitu :

1. Wanita sebagai istri.

Wanita tidak hanya sebagai ibu rumah tangga tetapi juga sebagai pendamping suami seperti sebelum menikah, sehingga dalam rumah tangga tetap terjalin ketentraman yang dilandasi kasih sayang yang sejati. Wanita sebagai istri dituntut untuk setia pada suami agar dapat menjadi motivator kegiatan suami.

2. Wanita sebagai ibu rumah tangga.

Sebagai ibu rumah tangga yang bertanggung jawab secara terusmenerus memperhatikan kesehatan rumah dan tata laksana rumah tangga, mengatur segala sesuatu didalam rumah tangga untuk meningkatkan 
mutu hidup. Keadaan rumah harus mencerminkan rasa nyaman, aman tentram, dan damai bagi seluruh anggota keluarga.

3. Wanita sebagai pendidik

Ibu adalah wanita pendidik pertama dan utama dalam keluarga bagi putraputrinya. Menanamkan rasa hormat, cinta kasih kepada Tuhan Yang Maha Esa serta kepada masyarakat dan orang tua. Pada lingkungan keluarga, peran ibu sangat menentukan perkembangan anak yang tumbuh menjadi dewasa sebagai warga negara yang berkualitas dan pandai.

Pada umumnya, di pedesaan suatu rumah tangga terlibat pada berbagai jenis pekerjaan. Hal ini terjadi karena bila dalam suatu rumah tangga hanya melibatkan diri pada suatu jenis pekerjaan biasanya pendapatan yang di peroleh tidak dapat mencukupi kebutuhannya. Oleh sebab itu anggota rumah tangga lainnya termasuk istri, akan berusaha mencukupi kebutuhannya dengan melibatkan diri pada berbagai jenis pekerjaan lain yang dapat menambah pendapatan rumah tangga Motif wanita tani bekerja pada usaha membuat atap rumbia adalah dari segi ekonomi, pendapatan suami yang kurang memcukupi kebutuhan rumah tangga, maka dari itu wanita mempunyai tugas untuk membantu pereknomian keluarga secara otomatis (Fatmawati dalam Rani, 2016 : 17).

Peranan wanita tani dalam membuat atap rumbia (istri) dalam ekonomi rumah tangga cukup besar. Wanita tani pembuat atap rumbia (istri) ternyata cukup produktif dalam mencari nafkah dalam memenuhi kebutuhan rumah tangganya mengingat pentingnya peranan istri (dalam hal ini wanita tani) dalam rumah tangga, maka besar manfaatnya untuk mengetahui keadaan keluarga petani terutama tentang peran wanita tani dalam mencari nafkah untuk mencapai kebutuhan keluarga.

\section{B. Konsep Pendapatan Keluarga}

Istilah pendapatan dalam berbagai bidang usaha/kegiatan banyak dimunculkan dengan berbagai pengertian seperti gross output, hasil penjualan, pendapatan keluarga, keuntungan dan sebagainya. Pendapatan bersih usahatani (net farm income) lebih banyak digunakan dalam analisis pendapatan usahatani. Pendapatan bersih petani berupa jumlah produksi dikalikan harga dikurangi dengan biaya produksi (widodo dalam Leni, 2010 : 48). Pendapatan adalah jumlah pendapatan yang diterima oleh para anggota masyarakat untuk jangka waktu tertentu 
sebagai balas jasa atas faktor-faktor produksi yang mereka sumbangkan dalam turut serta membentuk produk nasional. Menurut The Liang Gie dalam Hernanto (1994 : 390) memberikan pengertian income/pendapatan/penghasilan adalah seluruh pendapatan seseorang baik berupa uang maupun barang yang diperolehnya untuk suatu jangka waktu tertentu.

Pendapatan menurut Bishop dan Toussain dalam Leni (2010 : 49) merupakan selisih antara seluruh penerimaan dan seluruh pengeluaran (biaya produksi yang betul-betul dikeluarkan) dari berbagai cabang usahatani atau TR>TC. Bila untuk memperbesar pendapatan yaitu dengan memperbesar TR dan memperkecil TC. TR merupakan hasil perkalian antara output (Y) dengan harga output TR = Y. Py. TR semakin besar apabila Y semakin besar. Besarnya Y sangat berpengaruh oleh pemakaian faktor input, keadaan tanah, dan keadaan kondisi lingkungan sekitarnya. Selain itu, untuk memperbesar pendapatan dapat dengan memperkecil total biaya (TC). Total cost (TC) semakin kecil apabila rata-rata biaya persatuan output mengecil, hal ini dapat terjadi karena harga input menurun atau pemakaian input lebih efisien. Pendapatan secara sistematis dapat dirumuskan sebagai berikut :

$$
\begin{aligned}
& N R=T R-T C \\
& N R=T R-(T V C+T F C)
\end{aligned}
$$

Keterangan :

NR = Net Revenue/ Pendapatan

$\mathrm{TR}=$ Total Revenue/ Penerimaan Total

$\mathrm{TC}=$ Total Cost/ Biaya Total

TFC = Total Fixed Cost $/$ Biaya Tetap Total

TVC $=$ Total Variable Cost $/$ Biaya Variabel

\section{Total}

Menurut Sudarman dkk (2001), total biaya menggunakan persamaan sebagai berikut :

$$
\mathrm{TC}=\mathrm{TFC}+\mathrm{TVC}
$$

\section{Keterangan :}

$\mathrm{TC}=$ Total Biaya $($ Total Cost $) ;$

TFC = Total Biaya Tetap (Total Fixed Cost);

TVC = Total Biaya Variabel (Total Variabel

$$
\text { Cost). }
$$

Penerimaan usaha tani adalah perkalian antara produksi yang diperoleh dengan harga jual (Soekartawi, 2005). Penerimaan juga sangat ditentukan oleh besar kecilnya produksi yang dihasilkan dan harga dari produksi tersebut. Lebih lanjut stuktur penerimaan dari usaha 
wanita tani dalam membuat atap rumbia adalah sebagai berikut :

$$
\mathrm{TR}=\mathrm{Y} \times \mathrm{P}
$$

\section{Keterangan :}

$\mathrm{TR}=$ Total Penerimaan

$\mathrm{Y}=$ Jumlah produksi yang diperoleh

wanita tani dalam usaha membuat

atap rumbia $(\mathrm{Kg})$

$\mathrm{P}$ = Harga Produk (Rp).

C. Tinjauan Umum Peran Wanita Tani dalam Meningkatkan Pendapatan dalam Ekonomi Islam

Ekonomi Islam adalah suatu pengetahuan yang membantu upaya realisasi kebahagiaan manusia melalui alokasi dan distribusi sumber daya yang terbatas yang berada dalam koridor yang mengacu pada pengajaran Islam, tanpa mengekang kebebasan individu untuk menciptakan keseimbangan dan ekologi yang berkesinambungan (Capra dalam Riyadi dan Fauzia, 2014 : 7). Sedangkan Menurut Lubis dalam Leni (2016 : 6), Ekonomi Islam adalah sekumpulan dasardasar ekonomi yang berdasarkan Al-Quran dan Sunnah yang merupakan bagian perekonomian yang didirikan di atas landasan dasar-dasar tersebut sesuai dengan lingkungan dan masa. Dalam ekonomi Islam, berbagai jenis sumber daya dipandang sebagai pemberian atau titipan Tuhan kepada manusia. Manusia harus memanfaatkan seefisien dan seoptimal mungkin dalam produksi guna memenuhi kesejahteraan bersama yaitu untuk dirinya sendiri dan untuk orang lain.

Dalam Persfektif ekonomi Islam, sistem perekonomian mengandung aturan aturan Syara' yang dapat mengatur kehidupan perekonomian suatu rumah tangga, masyarakat, dan umat Islam secara keseluruhan. Suatu keharusan bagi seorang muslim untuk mengetahui prisip-prinsip dasar Ekonomi dalam Presfektif Islam agar dia tetap menempuh jalan lurus yang didasarkan pada hidayah Allah. Ketentuan perekonomian Islam mencangkup peraturan tentang pendapatan, pengeluaran (pembelanjaan), penyimpanan, penabungan dan pemilikan. Sumber daya manusia sangat penting dalam pembangunan ekonomi, baik itu sumber daya pria maupun wanita.

Eksistensi perempuan tidak hanya berdampak terhadap diri dan keluarga, tapi juga sangat berpengaruh terhadap masyarakat, bangsa dan negara. Bahkan kemajuan atau kehancuran negeri tergantung pada perempuan. Perempuan yang terdidik dengan baik akan melahirkan 
generasi yang baik dan memakmurkan negeri (Khomeini, 2004 : 45).

Peran perempuan dalam menopang ekonomi keluarga sangat penting, bahkan ada yang menjadi tulang punggung keluarga. Perjuangan yang mereka alami bukanlah takdir Allah SWT. Tak lain karena selama ini pemerintah sendiri tidak pernah memperhatikan hak-hak warganya. Khususnya para perempuan yang berdomisili di pedesaan. Mereka jarang mendapatkan pembinaan serta bantuan dari pemerintah, tak jarang posisi perempuan menjadi polemik di tengah masyarakat, ketika mereka harus bekerja untuk mempertahankan dapur supaya tetap mengepul. Bekerja serabutan akan dijalani, tidak peduli harus memeras keringat dan membanting tulang, seperti pada kelas pekerja buruh tani, pedagang sayur, penjahit dan lain-lain. Namun sayang, jasa perempuan dihargai jauh lebih rendah dari pada laki-laki, dengan anggapan bahwa kerja laki-laki lebih berat. Dengan begitu, posisi kaum laki-laki dianggap sebagai raja di dalam keluarga, masyarakat, organisasi, serta di tempat mereka bekerja, dan perempuan sebagai batur (pembantu), tetap kukuh dan tak tergoyahkan (sobary, 1999 : 83).
Islam telah menjamin hak perempuan untuk bekerja sesuai dengan tabiatnya dan aturan-aturan syariat dengan tujuan untuk menjaga kepribadian dan kehormatan perempuan. Meskipun demikian, Istri harus memiliki keyakinan bahwa yang utama dalam hidupnya adalah mengatur urusan rumah tangga. Sebagaimana Firman Allah SWT, dalam surat an-Nisaa' : 32 sebagai berikut :

Artinya: " Dan janganlah kamu iri hati terhadap kurnia yang telah dilebihkan Allah kepada sebagian kamu atas sebagian yang lain. (karena) bagi laki-laki ada bagian dari apa yang mereka usahakan, dan bagi perempuan (pun) ada bagian dari apa yang mereka usahakan. Mohonlah kepada Allah sebagian dari kurnia-Nya sungguh, Allah maha mengetahui segala sesuatu. ('S an-Nisa': 32).

Para mufassirin berkesimpulan bahwa di dalam ayat tersebut terbukti atas hak perempuan untuk bekerja. Dalam sejarah perjalanan Rasulullah telah membuktikan adanya partisipasi kaum perempuan dalam peperangan, dengan tugas mengurusi masalah pengobatan, menyediakan alat-alat, dan mengangkut prajurit yang terluka. Selain itu, telah terbukti bahwa terdapat sebagian perempuan yang menyebutkan diri dalam peniagaan dan membantu suami dalam 
pertanian. Wanita diperboleh bekerja menambah pendapatan keluarga tetapi harus tetap dapat memenuhi hak-hak suami dan anak-anaknya agar tidak terbengkalai.

Perempuan mempunyai peran ganda dalam keluarga yakni sebagai Ibu rumah tangga dan pencari nafkah. Peran ganda ini telah terlihat pada wanita tani dalam membuat atap rumbia di Kabupaten Konawe. Para wanita tani tersebut bekerja membuat atap rumbia dan menjadikannya sebagai pekerjaan tetap dan sampingan. Wanita tani bekerja tidak lain untuk meringankan beban yang ditanggung oleh seorang suami. Wanita tani dapat melakukan tugas sebagai tambahan dalam melakukan kewajiban seorang istri dalam memberikan kasih sayang dan cinta kasih kepada suami dan anak-anaknya, karena dengan bekerja tambahan tersebut berarti ia telah memberikan pemasukan lebih kepada sang suami dan membantu meningkatkan pendapatan keluarga.

Oleh karena itu, dalam upaya meningkatkan pendapatan keluarga wanita tani yang bekerja dalam usaha membuat atap rumbia, sebaiknya tetap memperhatikan ketentuan-ketentuan dalam Islam, di antaranya: Pertama, tidak boleh melalaikan tugasnya di sektor domestik, dan kedua, adalah mendapatkan ijin dari suaminya. Sehingga walaupun bekerja, akan tetapi ia tetap melaksanakan tugasnya dalam rumah tangga dengan baik, sehingga hak dan kewajiban dalam rumah tangga tidak terabaikan.

\section{METODE PENELITIAN}

\section{A. Waktu dan Lokasi Penelitian}

Penelitian ini dilaksanakan di Desa Tanggobu Kecamatan Lambuya Kabupaten Konawe. Penentuan lokasi penelitian dilakukan secara langsung (purposive), dengan pertimbangan bahwa lokasi tersebut merupakan salah satu daerah usaha pembuatan atap rumbia yang ada di Kabupaten Konawe dimana aktifitas wanita dalam usaha membuat atap rumbia lebih dominan dalam membantu meningkatkan pendapatan ekonomi keluarga.

\section{B. Populasi dan Teknik Pengambilan Sampel}

Populasi dalam penelitian ini adalah seluruh wanita tani pembuat atap rumbia yang berjumlah 23 orang. Teknik pengambilan sampel dilakukan dengan cara sensus yaitu dengan mengambil seluruh jumlah populasi (dalam hal ini semua wanita tani yang membuat atap 
rumbia) yang ada di Desa Tanggobu Kecamatan Lambuya Kabupaten Konawe.

\section{Jenis Dan Sumber Data} Jenis data yang digunakan pada penelitian ini adalah :

a. Data kualitatif yaitu data yang berbentuk kata, kalimat dan tanggapan. Data tersebut meliputi pernyataanpernyataan atau argumen-argumen mengenai sumber-sumber pustaka yang dimiliki berkaitan dengan peran wanita tani pembuat atap rumbia dalam meningkatkan pendapatan keluarga menurut perspektif ekonomi Islam di Kabupaten Konawe.

b. Data kuantitatif yaitu data yang berupa bilangan atau angka-angka, berdasarkan hasil kuisioner meliputi biaya, penerimaan, pendapatan wanita tani pembuat atap rumbia di Desa Tanggobu Kecamatan Lambuya Kabupaten Konawe.

Sumber data yang digunakan pada penelitian ini adalah :

a. Data primer yaitu data yang diperoleh langsung dari responden yang bersumber dari wawancara langsung responden.

b. Data sekunder adalah data yang diperoleh melalui cacatan yang diarsipkan oleh instansi terkait.

\section{Analisis Data}

Analisa data yang digunakan pada penelitian ini adalah analisa statistik deskriptif kualitatif dan kuantitatif yaitu dengan menghitung rata-rata penerimaan, pendapatan, persentase, dan melakukan penyederhanaan data serta penyajian data dengan menggunakan tabel distribusi frekuensi dan menjelaskan tentang peran wanita tani dalam usaha membuat atap rumbia menurut perspektif ekonomi Islam.

1. Untuk menganalisis tujuan penelitian pertama yaitu besarnya pendapatan yang diperoleh oleh wanita tani pembuat atap rumbia adalah dengan cara mengurangkan total penerimaan dengan total biaya, dengan rumus :

$$
\mathrm{NR}=\mathrm{TR}-\mathrm{TC}
$$

Dimana:

$$
\begin{aligned}
\mathrm{NR} & =\text { Pendapatan }(\text { Net Revenue }) \\
\mathrm{TR} & =\text { Total Penerimaan }(\text { Total revenue) } \\
\mathrm{TC} & =\text { Total Biaya }(\text { Total cost). }
\end{aligned}
$$

2. Untuk menganalisis tujuan kedua mengenai peran wanita tani pembuat atap rumbia dalam meningkatkan pendapatan keluarga menurut perspektif ekonomi Islam dengan yaitu menggunakan analisis deskriptif kualitatif. 


\section{HASIL DAN PEMBAHASAN}

\section{A. Karakteristik Responden}

Keterampilan pengusaha dalam mengelola usahanya akansangat mempengaruhi pada tingkat keberhasilan untuk mengantisipasi hambatan yang ada. Hambatan tersebut dapat berupa keadaan alam, sosial ekonomi pengusaha, bahkan juga kebijaksanaan baru dibidang pengusaha. Karakteristik responden yang diuraikan dalam hasil penelitian ini meliputi umur, tingkat pendidikan, jumlah tanggungan keluarga dan pengalaman berusaha.

\section{Umur}

Tingkat umur pengusaha sangat mempengaruhi kemampuan pengusaha baik fisik, cara berpikir dan cara mengelola usaha. Umur muda mempunyai kemampuan fisik yang lebih tinggi bila dibandingkan dengan umur tua. Untuk meningkatkan produktivitas suatu usaha, peranan tenaga kerja sangat strategis, Umur tenaga kerja sangat besar pengaruhnya sebab umur yang semakin tua akan dapat menurunkan produktivitas kerja. Hal ini disebabkan oleh kondisi fisiknya yang semakin menurun.

Hasil penelitian diketahui bahwa umur pengusaha responden usaha pembuatan atap rumbia di Desa Tanggobu Kecamatan Lambuya di Kabupaten Konawe bervariasi mulai dari 34-49 tahun. Untuk lebih jelasnya keadaan umur pengusaha responden dapat dilihat pada tabel 1 berikut :

Tabel 1. Keadaan Pengusaha Responden Menurut Kelompok Umur di Kecamatan Lambuya, Kabupaten Konawe Tahun 2016.

\begin{tabular}{|l|l|c|c|}
\hline No. & Umur (Tahun) & Jumlah (Jiwa) & Persentase(\%) \\
\hline 1. & $0-15$ (belum produktif) & - & - \\
2. & $16-50$ (produktif) & 23 & 100 \\
3. & $>50$ (kurang produktif) & - & - \\
\hline \multicolumn{2}{|c|}{ Jumlah } & 23 & 100 \\
\hline
\end{tabular}

Sumber: Data Primer Setelah Diolah, Tahun 2016.

2. Tingkat Pendidikan

Semakin tinggi pendidikan seseorang semakin mampu dalam menerima suatu informasi terutama dalam mengembangkan usahanya. Untuk mengetahui jenis tingkat pendidikan pengusaha responden di lokasi penelitian dilihat pada tabel berikut. : 
Tabel 2. Keadaan Responden Menurut Tingkat Pendidikan di Desa Tanggobu KecamatanLambuya, Kabuapten Konawe Tahun2016.

\begin{tabular}{|c|lc|c|c|}
\hline No. & Tingkat Pendidikan & Jumlah (Jiwa) & Persentase(\%) \\
\hline l. & SD & 5 & 22 \\
2. & SMP & 7 & 30 \\
3. & SMA & 11 & 48 \\
4. & Sl & - & - \\
\hline \multicolumn{2}{r|}{} & Jumlah & 23 & 100 \\
\hline
\end{tabular}

Sumber : Data Primer Setelah Diolah, Tahun 2016.

3. Pengalaman Berusaha

Pengalaman usaha dikatakan cukup apabila telah menggeluti bidang pekerjaan berusaha selama 5-10 tahun sedangkan 10 tahun keatas dikategorikan berpengalaman dan kurang dari 5 tahun dikategorikan kurang berpengalaman (Soeharjo dan Dahlan Patong, 1984). Gambaran mengenai pengusaha responden berdasarkan pengalaman berusaha dapat dilihat pada tabel berikut :

Tabel 3. Keadaan Responden Berdasarkan Pengalaman Berusaha di Desa Tanggobu Kecamatan Lambuya, Kabupaten Konawe Tahun 2016.

\begin{tabular}{|c|l|c|c|}
\hline No. & \multicolumn{1}{|c|}{ Pengalaman Berusaha (Tahun) } & Jumlah (Jiwa) & Persentase(\%) \\
\hline 1. & $<5$ (kurang berpengalaman) & 23 & 100 \\
2. & $5-10$ (cukup berpengalaman) & - & - \\
3. & $>10$ (berpengalaman) & - & - \\
\hline \multicolumn{2}{|c|}{ Jumlah } & 23 & 100 \\
\hline
\end{tabular}

Sumber: Data Primer Setelah Diolah, Tahun 2016.

4. Jumlah Tanggungan Keluarga

Jumlah tanggungan keluarga wanita tani responden di Desa Tanggobu Kecamatan Lambuya berkisar antara 1-7 orang. Dari jumlah anggota keluarga yang relatif kecil, berarti untuk membiayai usaha masih cukup memadai mengingat biaya keluarga yang dikeluarkan masih relatif kecil, status sosial ekonomi bawah adalah kedudukan seseorang di masyarakat yang diperoleh berdasarkan penggolongan menurut kekayaan, dimana harta kekayaan yang dimiliki termasuk kurang jika dibandingkan dengan rata-rata masyarakat pada umumnya serta tidakmampu dalam memenuhi kebutuhan hidup sehari-hari. Untuk mengetahui lebih jelasnya jumlah tanggungan keluarga responden dilokasi pengusaha, dapat dilihat pada tabel berikut: 
Tabel 4. Keadaan Jumlah Tanggungan Keluarga Responden di Desa Tanggobu Kecamatan Lambuya, Kabupaten Konawe Tahun 2016.

\begin{tabular}{|c|l|c|c|}
\hline No. & \multicolumn{1}{|c|}{ Jumlah Tanggungan Keluarga } & Jumlah (Jiwa) & Persentase(\%) \\
\hline 1. & $1-4$ (kecil) & 23 & 100 \\
2. & $5-7$ (sedang & - & - \\
3. & $>7$ (besar) & - & - \\
\hline \multicolumn{2}{|c|}{ Jumlah } & 23 & 100 \\
\hline
\end{tabular}

Sumber: Data Primer Setelah Diolah, Tahun 2016.

B. Analisis Pendapatan Wanita Tani 1.361.783. Untuk biaya tetap adalah sebesar dalam Usaha Pembuatan Atap Rp. 60.825 atau rata-rata biaya tetap Rumbia

\section{Penerimaan dan Biaya Total}

Besar kecilnya penerimaan dari usaha pembuatan atap rumbia ditentukan oleh besar kecilnya jumlah produksi yang dihasilkan dan harga jual produk tersebut. Semakin tinggi harga jual akan semakin tinggi penerimaan yang diperoleh pengusaha pembuatan atap rumbia. Besarnya biaya total penerimaan yang diterima oleh pengusaha pembuatan atap rumbia adalah sebesar Rp. 54.630.000 atau rata-rata penerimaan sebesar Rp. 2.375.217.

Sedangkan biaya Total adalah semua pengeluaran yang dikeluarkan oleh wanita tani sebagai pengusaha pembuat atap rumbia selama 1 periode produksi. Biaya total meliputi biaya variabel dan biaya tetap. Dalam penelitian ini jumlah biaya variabel adalah sebesar $\quad 31.321 .000$ atau rata-rata biaya variabel sebesar $\mathrm{Rp}$. sebesar 2.645. Sehingga jumlah biaya total yang dikeluarkan selama usaha pembuatan atap rumbia adalah sebesar Rp. 31.381 .825 atau rata-rata biaya total sebesar Rp. 1.364.427.

\section{Pendapatan Wanita Tani dalam Usaha Atap Rumbia}

Besar kecilnya pendapatan yang akan diterima pengusaha tergantung dari bagaimana kemampuan pengusaha dalam mengorganisir faktor-faktor produksi. Besarnya tingkat pendapatan usaha yang diperoleh merupakan ukuran keberhasilan usaha yang dikelolanya dan juga menggambarkan kemajuan ekonomi usahanya. Besarnya pendapatan usaha pembuatan atap rumbia yang digunakan oleh pengusaha responden di Kecamatan Lambuya dapat dilihat pada uraian berikut dengan formulasi :

$\mathrm{NR}=\mathrm{TR}-\mathrm{TC}$ 
$\mathrm{NR}=\mathrm{Rp} \cdot 54 \cdot 630.000,--\mathrm{Rp} \cdot 31.381 .825$,

$\mathrm{NR}=\mathrm{Rp} \cdot 23.248 .175,-$

Dilihat dari selisih penerimaan dan biaya yang dikeluarkan menunjukkan bahwa usaha pembuatan atap rumbia di Desa Tanggobu Kecamatan Lambuya Kabupaten Konawe memberikan pendapatan yang besar dengan rata-rata pendapatan memperoleh ssbesar Rp. 23.248.175, - atau rata-rata pendapatan adalah sebesar Rp. 1.010.790,-.

C. Peran Wanita Tani dalam Meningkatkan Pendapatan Keluarga Menurut Perspektif Ekonomi Islam

Dalam Islam bekerja atau berusaha dinilai sebagai kebaikan, dan kemalasan dinilai sebagai kejahatan. Nabi berkata : ibadah yang paling baik adalah bekerja/berusaha, dan pada saat yang sama bekerja merupakan hak sekaligus kewajiban. Pada suatu hari Rasulullah Saw menegur seseorang yang malas dan meminta-minta, seraya menunjukan kepadanya jalan kearah yang produktif. Rasulullah meminta orang tersebut menjual asset yang dimilikinya dan menyisihkan hasil penjualannya untuk modal membeli alat (kapak) untuk mencari kayu di tempat bebas dan menjualnya ke pasar. Beliaupun memonitor kinerjanya untuk memastikan bahwa ia telah mengubah nasibnya kearah kerja yang produktif (Nasution dkk, 2007 : 115).

Islam menganjurkan umatnya untuk memproduksi dan berperan dalam berbagai bentuk aktivitas ekonomi, pertanian, perkebunan, perikanan, perindustrian dan perdagangan. Bekerja adalah bagian dari ibadah dan jihad jika sang pekerja bersikap konsisten terhadap peratuaran Allah, suci niatnya, dan tidak melupakan-Nya. Demikian pula dengan bekerja seorang individu mampu memenuhi kebutuhannya, mencukupi kebutuhan keluarganya, dan berbuat baikkepada tetangganya. Semua hal tersebut tidak akan terwujud tanpa harta yang dapat diperoleh dengan bekerja. Mewujudkan kesejahteraan dan meningkatkan kehidupan yang layak bagi kaum Muslim merupakan kewajiban syar'i, yang jika disertai ketulusan niat akan naik pada tingkatan ibadah.

Bekerja mencari nafkah adalah kewajiban seorang suami sebagai kepala rumah tangga, tapi Islam juga tidak melarang perempuan untuk bekerja. Perempuan boleh bekerja, jika memenuhi syarat-syaratnya dan tidak mengandung hal-hal yang dilarang oleh syari'at Islam. Sebagaimana Firman Allah SWT dalam surat Al- Hujarat ayat 13 berikut ini : 
Artinya : Hai manusia, Sesungguhnya Kami menciptakan kamu dari seorang laki-laki dan seorang perempuan dan menjadikan kamu berbangsa-bangsa dan bersuku-suku supaya kamu saling kenal-mengenal. Sesungguhnya orang yang paling mulia diantara kamu disisi Allah ialah orang yang paling taqwa diantara kamu. Sesungguhnya Allah Maha mengetahui lagi Maha Mengenal .

(Departemen Agama: 2002 : 745).

Perintah ini mencakup laki-laki dan perempuan. Allah juga mensyariatkan berusaha atau melakukan kegiatan bisnis kepada semua hambanya, Karenanya seluruh manusia diperintah untuk berbisnis, berikhtiar dan bekerja, baik itu laki-laki maupun perempuan. Perempuan bekerja sesuai dengan profesi dan tabi'at keperempuanannya dan tidak melanggarkan batas-batas syariat adalah lebih baik dari pada para perempuan dalam kondisi yang membutuhkan ia harus bekerja, ia tidak berbuat apa-apa. Apalagi hasil yang di dapatkannya untuk memenuhi kebutuhan hidup keluarga dan meningkatkan pendapatan keluarga dari pada memintaminta, hal ini sangat di larang oleh agama. Maksudnya, apapun kondisi kita itu hendaklah kita berusaha dan bekerja keras dengan usaha sendiri atau dengan kata lain hasil yang diraih adalah hasil dari tangan sendiri, bukan dari hasil jadi peminta-minta (mengemis). Sebagaimana Sabda Rasullah SAW :

Artinya: "Sesungguhnya Allah telah memberikan izin kepada kamu (perempuan) tetapi izin keluar rumah itu hanya untuk memenuhi kebutuhan rumah tangga saja" (HR. Bukhari).

Perempuan juga dapat keluar rumah untuk bekerja karena unsur yang mendesak seperti tidak ada orang yang dapat mencukupi kebutuhan hidupnya atau memberi nafkah kepadanya. Meskipun demikian, istri (dalam hal ini wanita tani) sebaiknya menjaga agar toleransi tersebut tidak mengubah aturan utama masyarakat Islam, yaitu bahwa tugas utama. Perempuan/wanita adalah di dalam rumah tangganya. Toleransi itu jangan diasumsikan sebagai kebebasan yang liar sehingga istri melupakan tugas utamanya (Syahatah, 1998 : 139).

Di dalam Islam tidak ada larangan bagi seorang perempuan untuk bekerja atau melakukan suatu usaha mencari nafkah maupun ikut membantu meningkatkan perekonomian dan pendapatan keluarga selagi mendapat izin dari suami. Bahkan Islam melarang kepada 
seluruh umat muslim untuk berpangku tangan atau meminta-minta sebagai pengemis, gelandangan dan lain-lain selagi umat tersebut masih mampu untuk berusaha. Sebagaimana Firman Allah SWT dalam surat Al- Jumua'ah ayat 10 berikut ini :

Artinya : Apabila telah ditunaikan shalat, Maka bertebaranlah kamu di muka bumi dan carilah karunia Allah dan ingatlah Allah banyak-banyak supaya kamu beruntung. (QS Al-jumu'ah: 10).

Keikutsertaan kaum perempuan dalam berusaha atau bekerja mencari nafkah dalam Islam diwajibkan jika berada dalam dua kondisi, pertama jika seorang perempuan harus menanggung biaya sendiri beserta keluarga pada saat orang menanggungnya tidak ada atau sudah tidak berdaya atau apabila pendapatan suami tidak dapat mencukupi kebutuhan yang dibutuhkan. Kedua, dalam kondisi perempuan dianggap fardhu kifayah untuk melakukan suatu pekerjaan yang dapat membantu terjaganya eksistensi suatu masyarakat muslim. Dalam kondisi seperti ini, seorang perempuan harus bekerja (berusaha) sedapat mungkin menyeimbangkan kewajiban dengan tanggung jawabnya terhadap rumah tangga dan anak-anak. Peran wanita tani dalam usaha membuat atap rumbia di Tanggobu Kecamatan Lambuya di Kabupaten Konawe, merupakan suatu kegiatan usaha yang sangat efisien dalam meningkatkan pendapatan keluarganya dan bisa membantu kebutuhan ekonomi.

Usaha yang dilakukan oleh wanita tani pembuat atap rumbia dalam meningkatkan pendapatan keluarga merupakan usaha yang baik dan sejalan dengan syari'at Islam karena dilakukan dengan usaha dan niat yang baik, tidak adanya pelanggaran syari'at istri tidak meninggalkan kewajibannya dalam mengatur rumah tangga untuk membantu suaminya. Dari penjelasan di atas, dapat diambil kesimpulan bahwa secara umum, usaha perempuan sebagai pembuat atap rumbia untuk membantu meningkatkan perekonomian pendapatan keluarga boleh dilakukan karena tidak bertentangan dengan prinsip Ekonomi Islam.

\section{KESIMPULAN DAN SARAN}

\section{A. Kesimpulan}

Berdasarkan pembahasan hasil penelitian dapat disimpulkan :

1. Hasil analisis pendapatan menunjukkan bahwa pendapatan yang diperoleh wanita tani pembuat atap rumbia di Desa Tanggobu Kecamatan 
Lambuya Kabupaten Konawe sudah cukup optimal yaitu sebesar Rp.23.248.175,- atau rata-rata sebesar Rp.1.010.790,- per wanita tani dalam usaha membuat atap rumbia dalam satu bulan proses pembuatan.

2. Usaha yang dilakukan oleh wanita tani pembuat atap rumbia dalam meningkatkan pendapatan keluarga merupakan usaha yang baik dan sejalan dengan syari'at Islam karena dilakukan dengan usaha dan niat yang baik, yaitu untuk membantu meningkatkan perekonomian pendapatan keluarga, selagi mendapat izin dari suami. sehingga hal ini tidak bertentangan dengan prinsip ekonomi Islam. Bahkan Islam melarang kepada seluruh umat muslim untuk berpangku tangan atau meminta-minta sebagai pengemis, gelandangan dan lain-lain selagi umat tersebut masih mampu untuk berusaha.

\section{B. Saran}

Berdasarkan kesimpulan yang dikemukakan diatas maka disarankan kepada wanita tani pembuat atap rumbia agar perlu meningkatkan lagi usaha pembuatan atap rumbia, sehingga dapat memberikan dampak yang positif bagi kemajuan ekonomi keluarga. Dan diharapkan wanita tani sebagai istri dapat menyeimbangkan antara pekerjaan dengan kewajiban sebagai Ibu Rumah Tangga, sehingga tetap sejalan dengan konsep ekonomi Islam.

\section{DAFTAR PUSTAKA}

Ayatullah Khomeini, 2004). Kedudukan Wanita, (Jakarta: Pustaka Lentera).

BKKBN. 1995. Pendidikan Kesejahteraan Keluarga. Jakarta : BKKBN.

Depertemen Agama, Al-Quran dan Terjemahan, (Semarang: PT. Toha Putra, 2002)

Fauzia, Ika Yunia dan Abdul Kadir Riyadi. 2014. Prinsip Dasar Ekonomi Islam Perspektif Maqashid al-syari'ah. Jakarta: Prenadamedia Group.

Heru, D. S. 2001. "Pembagian Kerja Wanita dan Pria di Perkebunan Provinsi Lampung". Jurnal Agric Vol 8:2 (6p).

Imam Bukhari, Shahih Bukhari, (Beirut : Darl al-Fikri,t.th) Jilid II.

Kuswardinah, Asih. 2007. Ilmu Kesejahteraan Keluarga. Semarang: UNNES Press.

Lestari,R. Santoso,I. Sulastri, D. 1997. Kontribusi Wanita dalam Agribisnis Gula Semut di Kabupaten Blitar Propinsi Jawa Timur. Jurnal Penelitian Ilmu-Ilmu Sosial Vol. 9 No. 1 Februari.

Majid, Fitria, Faktor-faktor Yang 
Mempengaruhi Keputusan Perempuan

Berstatus Menikah Untuk Bekerja (Studi

Kasus : Kota Semarang), Skripsi Sarjana

Sl Program Ekonomika dan Bisnis

UNDIP, Semarang, 2012.

M. Sholahuddin. 2007. Azas-Azas Ekonomi Islam. Jakarta: PT.Raja Grafindo

Perseda.

Muhammad Sobary. 1999. Menakar Harga

Wanita, Wanita Dalam Budaya Dominasi

Simbolis dan Actual Kaum Lelaki.

Penerbit Bandung : Mizan.

Mustafa Edwin Nasution ddk, 2007.

Pengenalan Ekslusif Ekonomi Islam.

Jakarta, Penerbit Kencana Cet, ke-2.

Nurmayasari, Destia. 2014. Peran Anggota

Kelompok Wanita Tani (KWT) "Laras

Asri" pada Peningkatan Kesejahteraan

Keluarga (Studi Deskriptif di Dusun

Daleman Desa Kadirejo Kecamatan

Pabelan Kabupaten Semarang). Skripsi

Jurusan Pendidikan Luar Sekolah

Fakultas Ilmu Pendidikan Universitas

Negeri Semarang.

Pudjiwati, Sayogyo. 1997. Peranan Wanita Dalam Perkembangan Masyarakat Desa. Jakarta: CV Rajawali.

Saleh, Leni. 2010. Produktivitas dan Efisiensi Usaha Tani Tanaman Padi

Sawah di Kabupaten Konawe.

Tesis Unpublished Universitas Gadjah

Mada. Pascasarjana Program Studi

Ekonomi Pertanian Fakultas

Pertanian.Yogyakarta.
Saleh, Leni. 2012. Penentuan Sektor Ekonomi Unggulan dan Pengembangan Sub Sektor Unggulan Pertanian Terhadap Ketahanan Ekonomi Daerah di Kabupaten Konawe, Sulawesi Tenggara. Tesis Program Studi Ketahanan Nasional Jurusan Antar Bidang, Sekolah Pascasarjana Universitas Gadjah Mada. Yogyakarta.

Saleh, Leni. 2016. Perubahan Nilai Tukar Uang Menurut Perspektif Ekonomi Islam. Jurnal Studi Ekonomi Islam dan Bisnis Islam Li Falah. Volume 1. Nomor 1. IAIN Kendari.

Rani, Widya Ningsih. 2016. Analisis Kontribusi Pendapatan Wanita Tani Terhadap Total Pendapatan Keluarga di Kabupaten Konawe. Program Studi Agribisnis Universitas Lakidende. Unaaha.

Soekanto, S. 2009. Sosiologi Suatu Pengantar, Edisi Baru, Rajawali Pers. Jakarta.

Soekanto, Soerjono. 1992. Sosiologi Suatu Pengantar. Jakarta: CV. Rajawali.

Soekartawi. 2005. Agribisnis Teori dan Aplikasinya. PT Raja Grafindo Persada. Jakarta.

Sugiyono. 2011. Metode Penelitian Kuantitatif Kualitatifdan R $\sim$ D. Bandung: Alfabeta.

Zulmaizarna, 2009. Akhlak Mulia Bagi Para Pemimpin, (Bandung: Pustaka AlFikri. 